\title{
Impact of integrated pest management (IPM) module on major insect- pests of wheat and their natural enemies in North-western plains of India
}

\author{
Beant Singh and Poonam Jasrotia ${ }^{1}$ \\ ${ }^{1}$ Department of Plant Breeding and Genetics, Punjab Agricultural University, Ludhiana-141004, India \\ ${ }^{2} I C A R$ - Indian Institute of Wheat and Barley Research, Karnal-132001, India.
}

\section{Article history}

Received: 17 Apr., 2020

Revised: 30 July., 2020

Accepted: 14 Aug., 2020

\section{Citation}

Singh B and Jasrotia P 2020. Impact of integrated pest management (IPM) module on major insect-pests of wheat and their natural enemies in North-western plains of India. Journal of Cereal Research 12(2):114119. http://doi.org/10.25174/25822675/2020/100185

\section{*Corresponding author \\ Email: beant19@pau.edu}

@Society for Advancement of Wheat and Barley Research

\begin{abstract}
In order to sustain the wheat production in North-western plains of India, a study was conducted to test the integrated pest management (IPM) module with commonly used farmer's practices for the management of insect pests during 2017-18 and 2018-19. It was observed that aphid population was significantly lower in IPM plot (2.48-2.60 aphids/tiller) as compared to farmer's practices (13.93-16.46 aphids/ tiller) at peak period of their activity. At the same time, the population of coccinellids predators was significantly higher in IPM plots $(6.80$ beetle $/ \mathrm{m} 2)$ as compared to non-IPM plots $\left(1.26\right.$ beetles $\left./ \mathrm{m}^{2}\right)$ during 2017-18. The termite damage ranged from 2.48-2.96 per cent in farmer's practices while it was only $0.20-0.80$ per cent in IPM fields. Similarly, greater pink stem borer (PSB) damage was recorded in farmer's practices (0.96-2.48 per cent) as compared to IPM fields (0.46-0.68 per cent). The incidence of brown wheat mite (BWM) was recorded on maturing wheat and it was 2-5 fold higher in farmer's practice (11.7331.53 mites $\left./ 10 \mathrm{~cm}^{2}\right)$ as compared to IPM plots $\left(4.20-5.00\right.$ mites $\left./ 10 \mathrm{~cm}^{2}\right)$. Approximately 9 per cent increase in grain yield resulted in additional income of Rs. 9291/ha in IPM plot. Seed treatment, yellow sticky trap based monitoring of aphids and need based application of insecticide resulted in better control of insect-pests, effective conservation of natural enemies and higher returns.
\end{abstract}

Keywords: Impact, integrated pest management, insect-pest, natural enemies, wheat, India

\section{Introduction}

India is the second largest producer of wheat (Triticum aestivum L.) in the world after China. A record production of 101.20 million tonnes of wheat was witnessed during 2018-19 in India (Anonymous, 2019). The wheat production is seriously constrained by a number of biotic and abiotic factors resulting in 5-10 percent yield losses every year in North-western plains of India (Dhaliwal and Arora, 1996). Among the biotic factors, arthropod pest viz. aphids, pink stem borer (PSB), termites and brown wheat mite inflicted serious damage to the crop in Northwestern plains of India (Deol, 1987; Aggarwal et al., 2000). A complex of 4 aphid species viz. Rhopalosiphum padi, $R$. maidis, Sitobion miscanthi, S. avenae attack wheat crop. Aphids are small louse like insects which cause damage by sucking sap from leaves, stem and developing grains of wheat. The infested leaves turn pale, wilt and wear a stunted appearance. Depending upon the environmental conditions and varieties, the aphids cause 3-21\% grain yield losses in wheat (Singh and Deol, 2003). Termites (Odontotermes obesus and Microtermes obesi), pink stem borer Sesamia inferens (PSB) are other important insect-pests of wheat and their damage is observed in the month of December on 3-5 weeks old crop (Singh, 2012). Termite are $10-15 \mathrm{~mm}$ long with cream coloured body having dark brown head while PSB larvae is 25-35 mm long and has a pinkish-white body with dark brown head. Generally, termites cut the roots and underground stem portion of plants (Sharma et al., 2004) while PSB bores 
into the stem and kills central shoots forming 'dead hearts' (Deol, 2002). Brown wheat mite, Petrobia latens (BWM) is a small microscopic ( $0.5 \mathrm{~mm}$ long) reddish brown pests which causes damage by sucking sap from leaves, stem, awns and developing grains of wheat during the months of March-April. Among the several natural enemies, seven spotted lady bird beetle (Coccinella septempunctata), Syrphid fly and Chrysoperla are the predominant predators which extensively feeds on aphids in wheat agro-ecosystem,

To sustain the wheat production in North-western plains of India, there is an urgent need to minimize grain yield losses caused by pests in wheat. In the past, insect pests were controlled by extensive use of pesticides. However, due to problems of pest outbreak, development of resistance to insecticides, elimination of natural enemies, risk to human and animal health besides environmental pollution, integrated pest management (IPM) is considered as the best alternative (Rao et al., 1999). Hence, there is an urgent need to test a comprehensive IPM module in order to avoid economic damage in wheat crop. A wide range of techniques viz. cultural, mechanical, biological and chemical have been combined to develop IPM modules in wheat. The present study was conducted to test the multifaceted IPM module with widely used farmer's practices in North-western plains of India.

\section{Materials and methods}

The investigations were carried out under All India Coordinated Wheat and Barley Improvement Programme (AICW \& BIP) during rabi seasons of 2017-18 and 2018-19 at Punjab Agricultural University, Ludhiana ( $30^{\circ} 55^{\prime} \mathrm{N}, 75^{\circ}$ $54^{\prime} \mathrm{E}$ and $247 \mathrm{~m}$ above mean sea level). The experiments were carried out in 1000 square meter block divided into two halves, one half $\left(500 \mathrm{~m}^{2}\right)$ receiving the IPM technology and other half $\left(500 \mathrm{~m}^{2}\right)$ with farmer's practices. The wheat variety HD 2967 was grown using $100 \mathrm{~kg}$ seed/ ha in both IPM and non-IPM fields. The recommended agronomical practices were followed for crop growing in both treatments (Anonymous, 2017). The IPM module was synthesized for the management of insect-pests and pathogens in wheat and it's detailed description is given in Table 1. It was compared with normal plant protection practices followed by the farmer's for protecting their crop against insect-pest and diseases. The IPM module has been developed by comprising cultural, biological and chemical practices for the management of insect-pests and pathogens. Although, the module was developed and tested for both diseases and insect-pests but here only the findings about incidence of insect-pests have been provided.

Observations were recorded on incidence of major insect-pests i.e. termites, PSB, BWM, aphids and their natural enemies at peak period of their incidence. The population intensity of aphids was recorded by counting the number of aphids/tiller from randomly selected fifteen tillers from each plot at peak period (8th and 10th standard meteorological weeks) of their activity in the months of February-March. The observation on termite damage was recorded by counting damaged and total tillers from one square meter area from fifteen different spots at weekly intervals from each plot at 3, 4 and 5 WAS. The PSB and termite damaged tillers were counted and removed from the plot to avoid repeated counting of the same tillers during the crop season. The population build of BWM was recorded by tapping the mites on glycerine smeared slides and counting their number in $10 \mathrm{~cm}^{2}$ from randomly selected fifteen spots in each plot at peak period of their activity in the second fortnight of March (Khan et $a l ., 1977)$. The observations on the population of natural enemies viz. coccinellids, syrphid fly and chrysoperla were recorded from fifteen different spots of one square meter area at weekly interval during February-March from both IPM and non-IPM plots. The numbers of observations on insect count and per cent damage was recorded as replication for each treatment. At harvesting, grain yields were recorded from each plot and converted into $\mathrm{q} / \mathrm{ha}$. Net return in term of rupees and cost benefit ratios were worked out for comparison of IPM module and framers practices and net monetary gain. The data were subjected to one way analysis of variance at the 0.05 significance level (Gomez and Gomez, 1994).

\section{Results and discussion}

The data recorded on the arthropod pests, natural enemies and the various economic parameters in IPM and nonIPM plots during 2017-18 and 2018-19 are presented in Tables 2 and 3.

\subsection{Aphid and their natural enemies}

The population of aphids varied significantly between IPM module and farmer's practice. Aphids started appearing in the first fortnight of February, however their population remained low until the crop reached flag leaf stage (105 DAS). During rabi 2017-18, the aphids population was significantly lower in IPM plot (2.48 aphids/tiller) as compared to farmer's practices 
(13.93 aphids/tiller) on 105 days old wheat crop (Table 2). Thereafter, aphid population rose to 2.60 and 16.46 aphids/tiller in IPM and non-IPM plots, respectively, on 120 days old wheat crop. Similar trends were observed in aphid population recorded during rabi 2018-19 (Table 3). The natural enemies (Coccinellids, Syrphid fly and Chrysoperla) appeared on wheat crop a fortnight after the appearance of aphids. The population of syrphid fly and cchrysoperla was too low to be statistically analyzed, however significantly higher population of coccinellids was recorded in IPM plots $\left(6.80 \mathrm{beetle} / \mathrm{m}^{2}\right)$ as compared to non-IPM plots (1.26 beetles/ $\mathrm{m}^{2}$ ) on 120 days old crop during 2017-18. At the same time, the differences in the coccinellid beetles $/ \mathrm{m}^{2}$ were non-significant between IPM field and farmer's practice during 2018-19. The insecticides/bio-pesticides were sprayed in IPM field when incidence of aphid was observed in the border strip of field which prevented it's further spread into the interiors of the field. However, blanket application of insecticides were made at flag leaf stage in farmer's practice which did not allowed the population build up natural enemies in later case. This could be a possible reason for higher number of aphids in farmer's practices as compared to IPM module. The numbers of plants infested with aphids were also higher in farmer's practice.

\subsection{Termite and PSB damage}

There were some differences in termite and PSB damage between IPM module and farmer's practices. The termite and PSB damage appeared on 30 days old crop. The termite and PSB damage was 2.48 \& 0.96 per cent, respectively in farmer's practices while it was 0.20 \& 0.46 per cent, respectively in IPM field on 30 days old crop during 2017-18 (Table 2). Similarly termite and PSB damage was $2.96 \& 2.48$ per cent, respectively in farmer's practice and $0.80 \& 0.68$ per cent, respectively in IPM fields on 45 days old crop during 2017-18. Similar trend was observed during 2018-19 (Table 3). Farmers generally treat their seeds with fungicide but do not apply any insecticide treatment for the control of termites. Moreover, blanket soil application of chlorpyriphos or some other insecticide were made at the time of sowing which proved insufficient to control termites and PSB damage that normally infest 3-5 week old crop. However, timely and need based (applied only if pest attack is observed) soil application of fipronil $0.3 \mathrm{G}$ (Reagent) @ $17 \mathrm{~kg} / \mathrm{ha}$ mixed with $50 \mathrm{~kg}$ sand before first irrigation resulted in significant control of termites and PSB damage in IPM plots.

\subsection{Brown wheat mite}

The incidence of brown wheat mite was comparatively higher in farmer's practice $\left(31.53\right.$ mites $\left./ 10 \mathrm{~cm}^{2}\right)$ as compared to IPM plots $\left(5.00\right.$ mites $\left./ 10 \mathrm{~cm}^{2}\right)$ on 120 days old wheat crop during 2017-18 (Table 2). Similarly, during 2018-19, the brown wheat mites were significantly more in farmer's practice $\left(11.73 \mathrm{mites} / 10 \mathrm{~cm}^{2}\right)$ as compared to IPM plots $\left(4.20\right.$ mites $\left./ 10 \mathrm{~cm}^{2}\right)$. The need based application of thiamethoxam 25 WG @ 50g/ha or 5\% neem seed kernel powder (on border strips of field) used for aphid control in IPM plots also resulted in management of BWM.

Table 1. Different components of IPM module for pest management in wheat

\begin{tabular}{|c|c|c|}
\hline Components of IPM & IPM module & Farmer's practice \\
\hline Seed treatment & $\begin{array}{l}\text { - Seed treatment with combination of reduced dose of vitavax } \\
75 \text { WP@ } 2 \mathrm{~g}+\text { bioagent fungus Trichoderma viride @ } 4 \mathrm{~g} / \mathrm{kg} \\
\text { seed to avoid the disease like loose smut of wheat } \\
\text { Seed treatment with thiamethoxam70 FS@1 g/kg of seed to } \\
\text { avoid incidence of termite or aphids upto } 45 \text { days after sowing. }\end{array}$ & $\begin{array}{l}\text { Seed treatment with } \\
\text { tebuconazole } \\
\text { (a) } 1 \mathrm{~g} / \mathrm{kg} \text { seed }\end{array}$ \\
\hline Soil Treatment & $\begin{array}{l}\text { For termite or pink stem borer control, need based broadcasting } \\
\text { of fipronil } 0.3 \mathrm{G} \text { (Reagent)@17 kg/ha mixed with } 50 \mathrm{~kg} \text { sand at } \\
\text { the time of infestation in moisten wheat fields before or after first } \\
\text { irrigation. }\end{array}$ & $\begin{array}{l}\text { Blanket application of } \\
\text { insecticides viz. } \\
\text { chlorpyriphos@2.1/ha } \\
\text { or fipronil o,3 G/ha at } \\
\text { the time of sowing }\end{array}$ \\
\hline Cultural control & $\begin{array}{l}\text { - Installation yellow sticky traps@12 to 15/ha for monitoring } \\
\text { aphids incidence. }\end{array}$ & - No trap \\
\hline $\begin{array}{l}\text { Economic threshold } \\
\text { level based chemical } \\
\text { control }\end{array}$ & $\begin{array}{l}\text { Border rows spraying of thiamethoxam } 25 \text { WG@50g/ha } \\
\text { or } 5 \% \text { neem seed kernel powder considering the pest / aphids } \\
\text { economic injury level as } 5 \text { aphids/earhead. }\end{array}$ & $\begin{array}{l}\text { Blanket spray of } \\
\text { thiamethoxam 70 Ws @ } \\
20 \text { a.i. /ha at flag leaf } \\
\text { stage }\end{array}$ \\
\hline Biological control & $\begin{array}{l}\text { One sprays of either } 5 \% \text { neem seed kernel powder or } \\
\text { Metarhizium anisopliae } 1.15 \% \text { WP@ } 1 \mathrm{~kg} / \mathrm{ha} \text { liter water followed } \\
\text { by thiamethoxam } 25 \text { WG@ @ } 50 \mathrm{~g} / \mathrm{ha} \text { (if required) at an interval } \\
\text { of } 15 \text { days, after the notice of infestation for the control of wheat } \\
\text { aphid. }\end{array}$ & - No bio control \\
\hline
\end{tabular}


Table 2: Effect of treatments of IPM modules on pests of wheat during 2017-18

\begin{tabular}{|c|c|c|c|c|c|c|c|}
\hline Sr..No. & $\begin{array}{l}\text { Days } \\
\text { after } \\
\text { sowing }\end{array}$ & Treatments & $\begin{array}{l}\text { Avg. no. } \\
\text { aphids/ shoot }\end{array}$ & $\begin{array}{l}\text { Avg. } \\
\text { bird } \\
/ \mathrm{m} 2\end{array}$ & $\begin{array}{l}\text { Avg. } \\
\text { termite } \\
\text { infestation } \\
(\%)\end{array}$ & $\begin{array}{l}\text { Avg. no. } \\
\text { of mites } \\
/ 10 \mathrm{~cm} 2\end{array}$ & $\begin{array}{l}\text { Avg. stem } \\
\text { borer } \\
\text { infestation } \\
(\%)\end{array}$ \\
\hline$\overline{1 .}$ & 30 & $\begin{array}{l}\text { IPM } \\
\text { FP value }\end{array}$ & $\begin{array}{l}0 \\
0 \\
-\end{array}$ & $\begin{array}{l}0 \\
0 \\
\end{array}$ & $\begin{array}{c}0.2(1.54)^{*} \\
2.48(8.98)^{*} \\
(1.12)\end{array}$ & 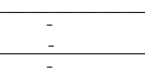 & $\begin{array}{c}0.44(3.15)^{*} \\
0.96(5.11)^{*} \\
(1.32))^{2}\end{array}$ \\
\hline 2. & 45 & $\begin{array}{l}\text { IPM } \\
\frac{\mathrm{FP}}{\mathrm{t} \text { value }}\end{array}$ & $\begin{array}{l}0 \\
0 \\
-\end{array}$ & $\begin{array}{l}0 \\
0 \\
-\end{array}$ & $\begin{array}{l}0.68(4.28)^{*} \\
\frac{2.94(9.84)}{(1.05)}\end{array}$ & - & $\begin{array}{l}0.80(5.08)^{*} \\
\frac{2.68(8.90)^{*}}{(0.99)}\end{array}$ \\
\hline 3. & 60 & $\begin{array}{l}\text { IPM } \\
\text { FP value }\end{array}$ & $\begin{array}{l}0 \\
0 \\
\end{array}$ & $\begin{array}{l}0 \\
0 \\
\end{array}$ & $\begin{array}{l}0 \\
0 \\
\end{array}$ & $\overline{-}$ & $\begin{array}{l}0 \\
0\end{array}$ \\
\hline 4. & 75 & $\begin{array}{l}\text { IPM } \\
\text { FP } \\
\text { t value }\end{array}$ & $\begin{array}{l}0 \\
0-1\end{array}$ & $\begin{array}{l}0 \\
0\end{array}$ & $\begin{array}{l}0 \\
0 \\
\end{array}$ & - & $\begin{array}{l}0 \\
0\end{array}$ \\
\hline 5. & 90 & $\begin{array}{l}\text { IPM } \\
\frac{\text { FP }}{\mathrm{t} \text { value }}\end{array}$ & $\begin{array}{l}0-1 \\
0-1\end{array}$ & $\begin{array}{l}0 \\
0\end{array}$ & $\begin{array}{l}0 \\
0\end{array}$ & - & $\begin{array}{l}0 \\
0\end{array}$ \\
\hline 6. & 105 & $\begin{array}{l}\text { IPM } \\
\text { FP } \\
\mathrm{t} \text { value }\end{array}$ & $\begin{array}{l}2.48(1.76)^{* * *} \\
13.93(3.83)^{* * *} \\
(0.51)^{*}\end{array}$ & $\begin{array}{l}0 \\
0 \\
\end{array}$ & $\begin{array}{l}0 \\
0 \\
\end{array}$ & - & $\begin{array}{l}0 \\
0 \\
\end{array}$ \\
\hline 7. & 120 & $\begin{array}{l}\text { IPM } \\
\text { FP } \\
\mathrm{t} \text { value }\end{array}$ & $\begin{array}{c}2.60(1.81)^{* *} \\
16.46(4.06)^{* *} \\
(0.63)\end{array}$ & $\begin{array}{c}6.80(2.75)^{* *} \\
1.26(1.44)^{* *} \\
(0.33)\end{array}$ & $\begin{array}{l}0 \\
0 \\
-\end{array}$ & $\begin{array}{l}5.00 \\
(2.38)^{* *} \\
31.53 \\
(5.65)^{* *} \\
0.36)^{*}\end{array}$ & $\begin{array}{l}0 \\
0\end{array}$ \\
\hline 8. & $\begin{array}{l}\text { Yield } \\
\text { (qt/ha) }\end{array}$ & $\begin{array}{l}\text { IPM } \\
\text { FP } \\
\text { t value }\end{array}$ & $\begin{array}{c}58.4 \mathrm{q} / \mathrm{ha} \\
52.8 \mathrm{q} / \mathrm{ha} \\
1.48\end{array}$ & & & & \\
\hline
\end{tabular}

IPM $=$ Integrated Pest Management; FP $=$ Farmer's Practice; * Figures in parentheses are arcsine transformed means, ${ }^{* *}$ Figures in parentheses are square root transformed means

Table 3: Effect of treatments of IPM modules on pests of wheat during 2018-19

\begin{tabular}{|c|c|c|c|c|c|c|c|}
\hline Sr...No. & $\begin{array}{l}\text { Days } \\
\text { after } \\
\text { sowing }\end{array}$ & Treatments & $\begin{array}{l}\text { Avg. no. } \\
\text { aphids/shoot }\end{array}$ & $\begin{array}{l}\text { Avg. } \\
\text { bird } \\
\text { /m2 }\end{array}$ & $\begin{array}{l}\text { Avg. } \\
\text { termite } \\
\text { infestation } \\
(\%)\end{array}$ & $\begin{array}{l}\text { Avg. no. } \\
\text { of mites } \\
110 \mathrm{~cm} 2\end{array}$ & $\begin{array}{l}\text { Avg. stem } \\
\text { borer } \\
\text { inferstation } \\
(\%)\end{array}$ \\
\hline 1. & 30 & $\begin{array}{l}\text { IPM } \\
\frac{\text { FP }}{\mathrm{t} \text { value }}\end{array}$ & $\begin{array}{l}0 \\
0 \\
\end{array}$ & $\begin{array}{l}0 \\
0 \\
\end{array}$ & $\begin{array}{l}0.17(1.455) * \\
2.79(9.59)^{*} \\
(1.20)\end{array}$ & - & $\begin{array}{c}0.32(2.48)^{*} \\
1.04(5.26)^{*} \\
(1.44)\end{array}$ \\
\hline 2. & 45 & $\begin{array}{l}\text { IPM } \\
\frac{\mathrm{FP}}{\mathrm{t} \text { value }}\end{array}$ & $\begin{array}{l}0 \\
0 \\
\end{array}$ & $\begin{array}{l}0 \\
0 \\
\end{array}$ & $\begin{array}{l}0.65(4.05)^{*} \\
\frac{2.76(9.53)^{*}}{(1.05)}\end{array}$ & 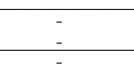 & $\begin{array}{l}0.63(3.87)^{*} \\
\frac{1.78(7.64)^{*}}{(0.99)}\end{array}$ \\
\hline 3. & 60 & $\begin{array}{l}\mathrm{IPM} \\
\mathrm{FP} \\
\mathrm{t} \text { value }\end{array}$ & $\begin{array}{l}0 \\
0 \\
-\end{array}$ & $\begin{array}{l}0 \\
0 \\
-\end{array}$ & $\begin{array}{l}0 \\
0 \\
\end{array}$ & - & $\begin{array}{l}0 \\
0\end{array}$ \\
\hline 4. & 75 & $\begin{array}{l}\text { IPM } \\
\text { t vP value }\end{array}$ & $\begin{array}{l}0 \\
0-1\end{array}$ & $\begin{array}{l}0 \\
0 \\
\end{array}$ & $\begin{array}{l}0 \\
0 \\
0\end{array}$ & $\overline{-}$ & $\begin{array}{l}0 \\
0 \\
\end{array}$ \\
\hline 5. & 90 & $\begin{array}{l}\text { IPM } \\
\frac{F P}{\mathrm{t} \text { value }}\end{array}$ & $\begin{array}{l}0-1 \\
0-1\end{array}$ & $\begin{array}{l}0 \\
0\end{array}$ & $\begin{array}{l}0 \\
0\end{array}$ & - & $\begin{array}{l}0 \\
0\end{array}$ \\
\hline 6. & 105 & $\begin{array}{l}\text { IPM } \\
\frac{F P}{t \text { value }}\end{array}$ & $\begin{array}{l}2.00(1.64)^{* * *} \\
\frac{9.73(3.26)^{* *}}{(0.27)}\end{array}$ & $\begin{array}{l}0 \\
0 \\
\end{array}$ & $\begin{array}{l}0 \\
0 \\
0\end{array}$ & - & $\begin{array}{l}0 \\
0\end{array}$ \\
\hline 7. & $\begin{array}{l}\text { At } \\
\text { earhead } \\
\text { stage }\end{array}$ & $\begin{array}{l}\text { IPM } \\
\text { FP } \\
\mathrm{t} \text { value }\end{array}$ & $\begin{array}{c}2.13(1.68)^{* *} \\
\frac{10.33(3.35)^{* *}}{(0.34)}\end{array}$ & $\begin{array}{c}4.06(2.16)^{* *} \\
2.73(1.87)^{* *} \\
\mathrm{NS}\end{array}$ & $\begin{array}{l}0 \\
0 \\
-\end{array}$ & $\begin{array}{l}4.20 \\
(2.26)^{* *} \\
11.73 \\
(3.49)^{* *} \\
0.42)\end{array}$ & $\begin{array}{l}0 \\
0 \\
-\end{array}$ \\
\hline 8. & $\begin{array}{l}\text { Yield } \\
\text { (qt/ha) }\end{array}$ & $\begin{array}{l}\frac{\text { IPM }}{\text { FP }} \\
\mathrm{t} \text { value }\end{array}$ & $\begin{array}{c}59.0 \mathrm{q} / \mathrm{ha} \\
53.9 \mathrm{~g} / \mathrm{ha} \\
1.26\end{array}$ & & & & \\
\hline
\end{tabular}

IPM = Integrated Pest Management; FP = Farmer's Practice; * Figures in parentheses are arcsine transformed means, ${ }^{* *}$ Figures in parentheses are square root transformed means 
Table 4: Economics of IPM in wheat

\begin{tabular}{|c|c|c|c|c|c|c|}
\hline \multirow[t]{2}{*}{ Parameters } & \multicolumn{2}{|l|}{$2017-18$} & \multicolumn{2}{|l|}{ 2018-19 } & \multicolumn{2}{|c|}{ Pooled mean } \\
\hline & IPM & FP & IPM & FP & IPM & FP \\
\hline Grain yield (q/ha) & 58.4 & 52.8 & 59.0 & 53.9 & 58.70 & 53.35 \\
\hline Gain over FP (q/ha) & 5.60 & - & 5.10 & - & 5.35 & - \\
\hline Yield gain (\%) & 9.58 & - & 8.64 & - & 9.11 & - \\
\hline Cost of crop protection/ha (Rs) & 1924 & 1690 & 1974 & 1690 & 1959 & 1690 \\
\hline Gross Returns (Rs) & $101324 /-$ & 91608/- & $108560 /-$ & 99176/- & 104942/- & 95392/- \\
\hline Net returns & 99400/- & 89918/- & 106586/- & 97486/- & 102983/- & 93702/- \\
\hline Net profit due to IPM (Rs) & $9482 /-$ & - & 9100/- & & 9291/- & \\
\hline
\end{tabular}

However, blanket application of thiamethoxam $25 \mathrm{WG}$ @ 50g/ha at flag leaf stage undertaken in farmer's practice resulted in significant reduction of coccinellid predators which ultimately resulted in higher population of BWM.

\subsection{Grain yield and economics:}

Significantly higher grain yield was obtained in IPM module (58.4 q ha-1) as compared to farmers's practice (52.8 kg ha-1) during rabi 2017-18. Similarly higher grain yield was also recorded in 2018-19. The 8.64-9.58 per cent gain in grain yield was recorded in IPM plot as compared to farmer's practice (Table 4). The cost of pesticides application was almost similar in IPM (Rs. 1959/ha) and non-IPM (Rs. 1690/ha) fields during the course of investigations. The pooled net return due to adoption of IPM were Rs 9291/-. The present findings are in line with the findings of Sabir et al. (2008) which recorded the higher cost benefit ratio in IPM module over farmer's practices in cotton crop. These findings are further corroborated with the results of Cufner (1994) which reported that IPM module helps in efficient control of insect-pests without appreciably affecting the natural enemies.

Overall, it can be concluded that with the adoption of IPM modules, farmers can reduce the pesticide pressure on crop and effectively manage the insect pests of wheat crop.

\section{References}

1. Aggarwal PK, SK Bandyopadhyay, H Pathak, N Kalra, S Chander and S Kumar 2000. Analysis of yield trends of the rice-wheat system in north-western India. Outlook on Agricuture 29(4): 259-268.

2. Anonymous, 2017. Package of Practices for Crops of Punjab. Rabi.Punjab Agricultural University,
Ludhiana. pp1-17.

3. Anonymous, 2019. Progress Report of All India Coordinated Wheat and Barley Improvement Project 2018-19, Project Director's Report. Ed: G.P. Singh, ICAR- Institute of Wheat and Barley Research, Karnal, Haryana, India. P 72.

4. Cunfer BM. 2009. Management of pests on wheat and other cereal crops with an IPM program. Food Revieres International 10 (2): 159-75.

5. Deol GS, KS Gill and JS Brar. 1987. Aphid out break on wheat and barley in Punjab. Neresletter Aphid Society of India 6: 7-9.

6. Deol GS. 2002. Latest Trends for Insect-pest Management in Wheat. Paper presented in specialized workshop on "Identification and management of weeds, insect-pests and diseases in wheat" held at CETWPT, PAU, Ludhiana.

7. Dhaliwal GS and R Arora. 1996. Principles of insect management. Commonwealth Publishers, New Delhi.

8. Gomez KA and AA Gomez. 1984. Statistical procedures for agricultural research (2 eds.). John wiley and sons, New York, 680 p.

9. Khan RN, VS Singh and JD Saxena. 1977. A simplified technique for sampling the brown wheat mite. Acarologia 19: 414-41.

10. Paroda RS and P Kumar, 2000. Food production and demand situations in South Asia. Agricultural Economics Research Review 13(4): 1-25.

11. Rao MS, GV Raman, G Srimannarayana and B Venkateshawaralu. 1999. Evaluation of some IPM packages in the management of pod borer complex 
of pigeon pea. Pestology: 23(8): 41-43.

12. Sabir N, TP Trivedi, J Singh, HR Sardana, A Dhandapani, AS Sohi, GS Dhaliwal and PD Sharma, 2008. Development and promotion of farmer participatory IPM technology in irrigated cotton cropping system- a case study- I. Pesticide Research Journal. 20: 38-42.

13. Sharma AK, KS Babu, S Nagarajan and M Kumar, 2004. Distribution and status of termite damage to wheat crop in India. Indian Journal of Entomology 66:
235-237.

14. Singh B and GS Deol, 2003. Quantative grain yield losses caused by aphid complex in wheat. Crop Research 26 (3): 501-504.

15. Singh B. 2012. Incidence of the pink noctuid stem borer, Sesamia inferens Walker, on wheat under two tillage conditions and three sowing dates in North-western plains of India. Journal of Entomology 9: 368-374. 